\title{
COMPARISON BETWEEN AMBLYOPIC AND OTHER NON-AMBLYOPIC EYES IN TERMS OF MACULA AND RETINAL NERVE FIBER LAYER THICKNESS
}

\author{
Ayyildiz Taha \\ Department of Opthalmology, Ahi Evran University Medicine Faculty, Kirsehir, Turkey \\ Prihvaćen/Accepted 04. 06. 2018. god.
}

Primljen/Received 26. 03. 2018. god.

Abstract: Statement of Significance: The prospect of this study is that the macula thickness is reduced in amblyopic eyes and may be a potential diagnostic tool in the future screening of amblyopic eyes. We did the unilateral anisometropic amblyopic patient comparison between amblyopic and non-ambliopic eyes in terms of average macular thickness and average retinal nerve fiber layer thickness with the help of spectral optical coherens tomography.

Material and Methods: The study included 74 over 6 year old patients with unilateral anisometropic amblyopia. Comparison between 74 amblyopic and 74 non-amblyopic eye in terms of average macular thickness and average retinal nerve fiber layer thickness, with the help of spectral optical coherens tomography (OPKO Instrumentations, Miami, FL). The difference between healthy and amblyopic eyes, mean macular thickness and retinal nerve fiber layer thickness were evaluated by Mann-Whitney U test.

Results: The mean age of the patients was $9.46 \pm$ 1.86 (7-14 years old) and 40 patients were female (54.05\%), 34 patients were male (45.95\%). Amblyopia group average macular thickness and mean retinal nerve fiber layer thickness respectively $235.31 \pm 21.3 \mathrm{mi}-$ cron $(\mu)$ and $100.96 \pm 11.45 \mu$ while non-amblyopia group average macular thickness and mean retinal nerve fiber layer thickness respectively $258.59 \pm 13.91 \mu$ and $103.68 \pm 14.55 \mu$. Although statistically significant difference $(\mathrm{p}=0.001)$ was observed with Mann-Whitney $U$ test in terms of macular thickness, while in terms of retinal nerve fiber layer the difference between two groups was not statistically significant $(\mathrm{p}=0,34)$.

Conclusions: Average macular thickness measurements taken with OCT device varies in anisometropic amblyopic eyes is an important concept for future studies.
Key words: Amblyopia, spectral oct, macular thickness.

\section{INTRODUCTION}

Amblyopia is the most common cause of unilateral visual loss in children. This is defined as a decrease in unilateral or bilateral uncorrected visual acuity due to visual deprivation and / or abnormal binocular interaction without an organic pathology $(1,2,3)$. The incidence varies from 0.5 to $3.5 \%$ (4). There are 3 main subgroups depending on strabismic, anisometropic and deprivation $(5,6)$. Functionally, amblyopic eye suppression results in loss of binocular functions of the binocular neurons in the visual cortex $(5,7,8)$. Histopathological changes in lateral geniculate nuclei in amblyopic eyes have been demonstrated in human and animal experiments (9-13).

The issue of retinal involvement in amblyopic eyes is controversial. Electroretinography (ERG) was significantly lower in the amblyopic eye in one study (14), while another study did not achieve the same result (15).

Optical coherence tomography (OCT) is a non-invasive, non-contact method of evaluating retina with axial resolution less than 10 microns using interferometry technique with near infrared laser beams. Retinal nerve fiber layer (RNFL) thickness measurements measured by OCT were similar to histological studies (16). It has been found that spectral OCT (S-OCT) measurements provide more detailed and accurate results than time-dependent OCT measurements (17).

The aim of this study was to compare the mean macular thickness and mean retinal nerve fiber thickness of the healthy and amblyopic eyes in cases of unilateral anisometropic amblyopia using S-OCT. 


\section{METHODS}

This cross-sectional observational study was performed between April 2017 and March 2018 in Ahi Evran University Education and Research Hospital, Department of Ophthalmology. The research was carried out in accordance with Helsinki declaration rules and with informed consent forms of patients.

In this study, patients over 6 years of age, diagnosed with unilateral anisometropic amblyopia, were evaluated for amblyopic and non amblyopic eyes. A comprehensive ophthalmologic examination was performed on all cases. Refractions of the patients before and after cycloplegic instillation with autorefractometer were determined.

Uncorrected visual acuity (UCVA) and best corrected visual acuity (BCVA) were obtained with Snellen's sphere at a distance of $6 \mathrm{~m}$ without cycloplegic effect. In all cases, a goldmann applanation tonometer was used to measure intraocular pressure, a biomicroscopic evaluation to assess anterior segment and a dilate fundus examination. In addition, strabismus examination was performed to all cases.

One eye had a visual acuity of at least 20/20, and the other eye's visual acuity less then non-amblyopic eye at least two lines and an eye pathology that could affect the eye other than anisometropia could not be determined were accepted as amblyopia. Two diopters (D) spherical equivalents and one diopter (D) refraction difference between the two eyes were accepted as anisometropia.

Macula and optic disc in ambliyopic and intact eyes were photographed with OCT (OPKO Instrumentations, Miami, FL,USA). Spectral OCT / SLO (OPKO / OTI Instru- mentation, Miami, FL, USA) was used. The device provides spectral OCT and SLO images of the tissues at the same time, at the time of scanning approximately $27,000 \mathrm{~A}$-scan per second, using "super luminescent diode" light at 830-840 nm wavelength. The axial resolution is 5-6 $\mu \mathrm{m}$, the posterior resolution is $15 \mu \mathrm{m}$, and the scan depth is $2.3 \mathrm{~mm}$ (18). In all cases, a $3.4 \mathrm{~mm}$ diameter peripapillary RLL thickness measurement was performed in an RSLT mode of the device by an experienced OCT user. The device takes averages of 3 peripapillary measurements as standard. These three measurements were also taken from us and were not taken into account if there are cross-sections with RSLT boundary detection error or signal-to-noise ratio less than $50 \%$. In the RSLT mode, the device receives thickness measurement; mean RNFL thickness, superior-nasal-inferior-temporal, and 8-hour quadrant thicknesses. The mean macular thickness was adjusted to $512 \times 64$ maculer cubes with the instrument set to OCT mode.
The obtained data was recorded in the computer "SPSS" (statistical package for social sciences) for Windows "15". The Kolmogorov-Smirnov test was used to show that the data of the groups were not homogeneously distributed $(\mathrm{p}=0.001)$. The difference between the 2 independent groups was assessed by the Mann-Whitney $\mathrm{U}$ test, a nonparametric test. When the p-value was less than 0.05 , the results were considered significant.

\section{RESULTS}

In 74 patients with unilateral anisometropic amblyopia, 74 amblyopic and 74 non-ambliyopic eyes were evaluated. The mean age of the patients was 9,46 $\pm 1,86$ (7-14 years); 40 patients were female $(54,05 \%)$ and 34 patients were male $(45,95 \%)$.

The average macula thickness in the amblyopic group was $235.31 \pm 21.33$ and the mean retinal nerve fiber thickness was $100.96 \pm 11.45$; mean macular thickness was $258.59 \pm 13.91$ and mean retinal nerve fiber thickness was $103.68 \pm 14.55$ in the non-amblyopic group. The Mann-Whitney U test was used to compare two independent groups after demonstration with the help of the Kolmogorov-Smirnov test $(\mathrm{p}=0.001$ and 0.0001$)$.

Mean macular thickness was significantly lower in amblyopic eye group $(p=0.001)$, but there was no statistically significant difference between two groups in terms of mean RNFL thickness $(p=0,34)$.

\section{DISCUSSION AND CONCLUSION}

Different results have been reported in studies in which retinal thicknesses of the amblyopic and intact eyes were evaluated. When we looked at the literature, Yen (19) and Yoon (4) Peripapillary RSLT analyzes revealed a statistically significant height in amblyopic group; Altintas (7), Kee (5) and Repka (20) did not show any statistically significant difference between these two groups. Yoon et al. reported that there was no difference in macular thickness between the unilateral anisometropic amblyopia and amblyopic eyes and that the RNFL thickness was thicker in amblyopic eyes (4). Dickmann et al. anisometropic amblyopia, and strabismus amblyopia, there was no statistically significant difference between the macula and RNFL thickness of the amblyopic and non-amblyopic eyes (21). As a result of our study, statistically significant decrease in average macular thickness was observed $(p=0,001)$, unlike previous studies, and no statistically significant difference was found in terms of mean RNFL thickness as similar to the previous studies $(\mathrm{p}=0,34)$.

Amblyopia studies have shown that atrophy occurs in lateral geniculate cells (22). In animal studies, reduction of optic nerve dimensions in amblyopic 
eyes, ganglion cytoplasm and thinning in internal plexiform layer were detected (23).

It is important to be diagnosed as early as possible. Because the earlier the diagnosis is made, the greater the likelihood of treatment. We think that pathologic findings detected in the brain in histological studies can be detected with OCT also in RSLT, which may be useful in the detection of amblyopia. In some studies amblyopia was observed with macular thickness in the eyes and no difference was observed in some studies as we showed in our study with RNFL thicknesses.

There are many factors that affect the reproducibility and manufacturability of OCT images. These include patient co-operation, fixation, and refraction (24). In addition, it has been reported that retinal thickness values obtained with different brand and model OCT devices can not be used in place of each other due to the different measurement algorithms used in the devices, but the reproducibility and manufacturability of measurements taken in the same way are quite high (24). In addition to device factors, patient characteristics can also affect the outcome of OCT. When the level of vision is low, the fixation of the cases becomes difficult and the quality of the shot is reduced and the reliability of the results of OCT to be used for follow-up of the cases is reduced.
As a result, there was a statistically significant difference between the macular thicknesses measured by spectral OCT in children with unilateral anisometropic amblyopia. It is clear that this result we obtained should be supported by extensive participatory randomized studies, but we still think it may be important to follow up with this imaging method which is likely to become a valuable follow-up tool in the future of amblyopia cases.
Abbreviations
ERG - Electroretinography
OCT - Optical coherence tomography
RNFL - Retinal nerve fiber layer
UCVA - Uncorrected visual acuity
BCVA — best corrected visual acuity

\section{DECLARATION OF INTEREST}

The autors declare that there are no conflicts of interests.

\section{Licensing}

This work is licensed under a Creative Commons Attribution 4.0 International (CC BY 4.0) License.

\title{
Sažetak
}

\section{POREĐENJE IZMEĐU AMBLIOPNIH I NEAMBLIOPNIH OČIJU U POGLEDU DEBLJINE MAKULE I DEBLJINE SLOJEVA NERVNIH VLAKANA RETINE}

\author{
Ayyildiz Taha \\ Department of Opthalmology, Ahi Evran University Medicine Faculty, Kirsehir, Turkey
}

Uvod: Prospekt ove studije je to da je debljina makule manja kod ambliopnih očiju i može predstavljati potencijalno dijagnostičko sredstvo u budućem skriningu ambliopije. Izveli smo poređenje kod unilateralne anizometropijske ambliopije između ambliopnog i drugog neambliopnog oka u pogledu prosečne debljine makule i prosečne debljine retinalnih nervnih slojeva, uz pomoć spektralne optičke koherentne tomografije.

Materijal i metode: Studija je uključila 74 pacijenta preko 6 godina sa unilateralnom anizometrijskom ambliopijom. Poređenje između 74 ambliopna i 74 neambliopna oka u pogledu prosečne debljine makule i prosečne debljine nervnih slojeva retine uz pomoć spektralne optičke koherentne tomografije (OPKO Instrumentations, Miami, FL). Razlika između zdravog i ambliopnog oka, prosečna vrednost debljine makule i prosečna debljina slojeva nervnih vlakana retine su bili procenjeni korišćenjem Mann-Whitney U testa.
Rezultati: Prosečna vrednost godina pacijenata bila je $9.46 \pm 1.86$ (7-14 godina života) i 40 pacijenata su bile Žene (54,05\%), 34 pacijenta su bili muškarci (45,95\%). U grupi ambliopnih očiju srednja makularna debljina i srednja debljina slojeva nervnih vlakana retine bila je 235,31 \pm 21.3 mikrona $(\mu)$ i $100,96 \pm 11,45 \mu$, dok je u grupi neambliopnih očiju prosečna makluarna debljina i prosečna debljina slojeva nervnih vlakana retine respektivno $258,59 \pm 13,91 \mu$ i 103,68 $\pm 14,55 \mu$. Iako je statistički značajna razlika bila viđena koristeći Mann-Whitney U test u pogledu makularne debljine, kod srednje debljine slojeva nervnih vlakana retine nije bila nađena statistički značajna razlika između grupa $(p=0,34)$.

Zaključak: Prosečna debljina makule određivana pomoću OCT-a razlikuje se u anizometrijskom ambliopnom oku u odnosu na drugo neambliopno oko i može se posmatrati kao zanačajna osnova za buduće studije.

Ključne reči: ambliopija, spektralna optička koherentna tomografija, makularna debljina. 


\section{REFERENCES}

1. Wright KW. Visual development and amblyopia. In: Wright KW, Spiegel PH, eds. Pediatric Ophthalmology and Strabismus. New York: Springer. 2003: 157-71.

2. Von Noorden GK. Amblyopia: a multidisciplinary approach. The Proctor lecture. Invest Ophthalmol Vis Sci. 1985; 26(12): 1704-16.

3. Campos E. Amblyopia: major review. Surv Ophthalmol. 1995; 40(1): 23-39.

4. Yoon SW, Park WH, Baek SH, Kong SM. Thicknesses of macular retinal layer and peripapillary retinal nerve fiber layer in patients with hyperopic anisometropic amblyopia. Korean J Ophthalmol. 2005; 19(1): 62-7.

5. Kee SY, Lee SY, Lee YC. Thickness of the fovea and retinal nerve fiber layer in amblyopia and normal eyes in children. Korean J Ophthalmol. 2006; 20(3): 177-81.

6. Von Noorden GK. Classification of amblyopia. Am J Ophthalmol. 1967; 63(2): 238-44.

7. Altinas O, Yuksel N, Ozkan B, Caqlar Y. Thickness of the retinal nerve fiber layer, macular thickness, and macular volume in patients with strabismic amblyopia. J Pediatr Ophthalmol Strabismus. 2005;42(4):216-21.

8. Bozkurt B, Irkec M, Orhan M, Karaa - ao-lu E.Thickness of the retinal nerve fiber layer in patients with ansiometropic and strabismic amblyopia. Strabismus. 2003; 11(1): 1-7.

9. Wiesel TN, Hubel DH. Single-cell responses in striate cortex of kittens deprived of vision in one eye. J Neurophysiol. 1963; 26: 1003-17.

10. Von Noorden GK. Histological studies of the visual system in monkeys with experimental amblyopia. Invest Ophthalmol. 1973; 12(10): 727-38.

11. Von Noorden GK, Middleditch PR. Histology of the monkey lateral geniculate nucleus after unilateral lid closure and experimental strabismus: further observations. Invest Ophthalmol. 1975;14(9):674-83.

12. Von Noorden GK, Crawford ML, Levacy RA. The lateral geniculate nucleus in human anisometropic amblyopia. Invest Ophthalmol Vis Sci. 1983; 24(6): 788-90.

\author{
Correspondence to/Autor za korespondenciju \\ Taha AYYILDIZ \\ Assistant Professor \\ Ahi Evran University Medicine Faculty \\ Department of Opthalmology Kaersehir, Türkey \\ email: obirtahadir@hotmail.com \\ tel: 00905077559720
}

13. Von Noorden GK, Crawford ML. The lateral geniculate nucleus in human strabismic amblyopia. Invest Ophthalmol Vis Sci. 1992; 33(9): 2729-32.

14. Arden GB, Wooding SL. Pattern ERG in amblyopia. Invest Ophthalmol Vis Sci. 1985; 26(1): 88-96.

15. Deline PJ, Weissenbruch C, Berendschot TT, Norren DV. Photoreceptor function in unilateral amblyopia. Vision Res. 1998; 38(4): 613-7.

16. Huang D, Swanson EA, Lin CP, Schuman JS, Stinson WG, Chang W, et al. Optical coherence tomography. Science. 1991; 254(5035): 1178-81.

17. Geitzenauer W, Kiss CG, Durbin MK, Abunto MT, Callan TM, Stetson PF, et al. Comparing retinal thickness measurements from cirrus spectral domain- and stratus time domain-optical coherence tomography. Retina. 2010; 30(4): 596-606.

18. Spectral OKT/SLO combination imaging system kullan2m kitab2. OPKO/OTI Instrumentation, Miami, FL, USA. December 2007.

19. Yen MY, Cheng CY, Wang AG. Retinal nerve fiber layer thickness in unilateral amblyopia. Invest Ophthalmol Vis Sci. 2004; 45(7): 2224-30.

20. Repka MX, Cohen NG, Edwards AR. Retinal nerve fiber later thickness in amblyopic eyes. Am J Ophthalmol. 2006;142(2):247-51.

21. Dickmann A, Petroni S, Perrotta V, Parrilla R, Aliberti $\mathrm{S}$, Salerni A, et al. Measurement of retinal nerve fiber layer thickness, macular thickness, and foveal volume in amblyopic eyes using spectral-domain optical coherence tomography. JAAPOS. 2012; 16(1): 86-8.

22. Friedmann Z, Neumann E, Hyams SW, Peleg B. Ophthalmic screeningof 38,000 children, age 1 to 2.5 years, in child welfareclinics. J Pediatr Ophthalmol Strabismus. 1980; 17(4): 261-7.

23. Russell EL, Kada JM, Hufhines DM. Orange County vision screening project. Ophthalmologic evaluation. Sight Saving Rev. 1961; 31: 215-9.

24. Sung KR, Kim DY, Park SB, Kook MS. Comparison of retinal nerve fiber layer thickness measured by Cirrus HD and Stratus optical coherence tomography. Ophthalmology. 2009; 116(7): 1264-70. 